\title{
Prevalensi Seropositif Antibodi Anti-rubela pada Mahasiswi Fakultas Kedokteran Universitas Indonesia Jakarta: Upaya untuk Menurunkan Angka Kejadian Sindrom Rubela Kongenital
}

\section{Elsye Souvriyanti, Sri Rezeki S Hadinegoro, I Budiman}

Divisi Infeksi dan Penyakit Tropis Departemen Ilmu Kesehatan Anak Fakultas Kedokteran Universitas Indonesia Rumah Sakit Dr. Ciptomangunkusumo Jakarta

Latar belakang. Infeksi rubela pada ibu hamil dapat mengakibatkan komplikasi yang serius pada janin. Maka remaja perempuan sebagai calon ibu harus telah mempunyai kadar antibodi anti-rubela yang tinggi. Tujuan. Penelitian ini dilakukan untuk mengetahui prevalensi seropositif terhadap antibodi anti-rubela pada remaja perempuan sebagai upaya untuk menurunkan angka kejadian sindrom rubela kongenital. Metode. Penelitian deskriptif potong lintang, dilakukan terhadap 97 orang mahasiswi tingkat I dan II Fakultas Kedokteran Universitas Indonesia, yang dipilih secara konsekutif pada bulan Mei-Juni 2007.

Hasil. Usia rerata subjek 18,9 tahun ( $\mathrm{SD}=1,0)$. Imunisasi MMR didapatkan pada 19 dari 97 subjek penelitian (19,6\%). Angka seropositif terhadap antibodi anti-rubela 71 subjek $(73,2 \%)$ rerata kadar antibodi anti-rubela 159,7 UI/ml $(\mathrm{SD}=107,4)$. Proporsi seropositif antibodi anti-rubela yang diperoleh melalui imunisasi MMR 19 dari 71 subjek (26,8\%) nilai rerata kadar antibodi anti-rubela 148,9 UI/ml (SD = 86,4). Proporsi seropositif antibodi anti-rubela yang diperoleh melalui infeksi alamiah 52 dari 71 subjek $(73,2 \%)$ rerata kadar antibodi anti-rubela $163,6 \mathrm{UI} / \mathrm{ml}(\mathrm{SD}=114,7)$.

Kesimpulan. Prevalensi seropositif antibodi anti-rubela 73,2\%. Imunitas yang ditimbulkan dengan pemberian imunisasi MMR sama dengan imunitas yang diperoleh dari infeksi alamiah. (Sari Pediatri 2007; 9(3):157-162).

Kata kunci: rubela, sindrom rubela kongenital, prevalensi antibodi anti-rubela

Alamat korespondensi

Prof. DR. Dr. Sri Rezeki S Hadinegoro, Sp.A(K).

Divisi Infeksi dan Penyakit Tropis, Departemen Ilmu Kesehatan Anak FKUI-RSCM, Jl. Salemba no. 6 Jakarta 10430.

Tel. 391 4126. Fax. 3907743.

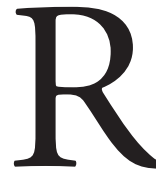

ubela merupakan penyakit yang disebabkan oleh virus RNA yang menular melalui droplet atau kontak langsung. Pada sebagian besar kasus, terutama pada anak penyakit ini bersifat asimtomatis, pada usia yang 
lebih besar dapat menyerupai gejala flulike symptoms dan bersifat ringan. Gejala klinis diawali dengan demam, ruam makulopapular yang bersifat sementara, limfadenopati terutama pada kelenjar getah bening postauricular, suboksipital, dan servikal, kadangkadang disertai artritis dan artralgia. Rubela pada ibu hamil dapat mengakibatkan komplikasi yang serius pada janin berupa kematian janin, kelahiran prematur, cacat bawaan atau sindrom rubela kongenital terutama bila ibu hamil terinfeksi pada trimester pertama kehamilan. ${ }^{1-3}$

Rubela merupakan penyakit yang bersifat epidemik. Pada tahun 1993 Centers for Disease Control and Prevention (CDC) mencanangkan eliminasi rubela di Amerika Serikat pada tahun 2000, tetapi pada tahun 2001-2004 masih dilaporkan 9 kasus rubela dan 4 kasus sindrom rubela kongenital. Oleh karena itu, rubela merupakan masalah kesehatan yang penting di berbagai negara. ${ }^{4-7}$ World Health Organization (WHO) memperkirakan 100.000 kasus sindrom rubela kongenital terjadi setiap tahunnya terutama di negara berkembang. ${ }^{4}$ Data dari rekam medik Poliklinik Departemen Ilmu Kesehatan Anak Rumah Sakit Cipto Mangunkusumo (IKA RSCM) tercatat 63 kasus sindrom rubela kongenital pada periode 1997-2006.

Imunisasi terhadap rubela bertujuan untuk mencegah lahirnya bayi dengan sindrom rubela kongenital dan telah dimulai sejak tahun $19699^{4,6,7}$ Negara yang sudah memasukkan vaksin rubela dalam program imunisasi rutinnya telah berhasil menurunkan angka kejadian rubela sekaligus kasus sindrom rubela kongenital. ${ }^{4,6,8-10}$ Antibodi anti-rubela dapat terjadi melalui infeksi alamiah atau melalui pemberian vaksin. Titer antibodi anti-rubela yang terbentuk akan menurun dengan bertambahnya waktu. ${ }^{6-9}$ Mengingat tujuan vaksinasi rubela untuk mencegah sindrom rubela kongenital, maka remaja perempuan sebagai calon ibu harus telah mempunyai kadar antibodi antirubela yang tinggi. Atas dasar hal tersebut, akan dilakukan penelitian yang bertujuan untuk mengetahui prevalensi antibodi anti-rubela pada remaja perempuan.

\section{Metode}

Penelitian ini merupakan penelitian deskriptif, potong lintang untuk mengetahui prevalensi seropositif antibodi anti-rubela pada remaja perempuan. Penelitian dilakukan di Departemen
Ilmu Kesehatan Anak Fakultas Kedokteran Universitas Indonesia Jakarta, bulan Mei sampai Juni 2007. Populasi terjangkau adalah semua mahasiswi Fakultas Kedokteran Universitas Indonesia tingkat I dan tingkat II. Subjek penelitian semua populasi terjangkau yang berbadan sehat, tidak mendapat terapi imunoglobulin atau terapi imunosupresan dalam 3 bulan terakhir, dan bersedia mengikuti penelitian. Pengambilan sampel dilakukan secara konsekutif.

Subjek yang memenuhi kriteria penelitian, diminta menandatangani formulir persetujuan ikut serta dalam penelitian dan mengisi formulir penelitian. Pengisian formulir mengenai status imunisasi MMR berdasarkan buku catatan imunisasi atau bila buku catatan imunisasi tidak ada, berdasarkan anamnesis dengan orangtua subjek. Pemeriksaan titer antibodi dilakukan dengan teknik Enzyme Linked Fluorescent Assay (Vidas ${ }^{\circledR}$ Rub Ig G, bio Merieux, Perancis) di Laboratorium Makmal Terpadu Imunoendokrinologi FKUI. Pemeriksaan dengan tekhnik ini mempunyai sensitivitas $97,7 \%$ dan spesifisitas $100 \% .{ }^{11}$ Titer dianggap seropositif bila $\geq 15 \mathrm{IU} / \mathrm{ml}$. Titer seropositif merupakan angka seroprotektif. Izin penelitian telah didapat dari Komite Etik FKUI.

Data diolah dengan menggunakan program SPSS versi 13.0, sehingga dapat dianalisis sesuai dengan tujuan penelitian. Data yang bersifat deskriptif akan disajikan dalam bentuk narasi dan tabel.

\section{Hasil Penelitian}

\section{Karakteristik Subjek Penelitian}

Selama kurun waktu penelitian terdapat 97 subjek yang memenuhi kriteria penelitian. Usia rerata seluruh subjek penelitian 18,9 tahun $(\mathrm{SD}=1,0)$ dengan sebaran usia antara 17 tahun sampai dengan 21 tahun. Riwayat infeksi rubela hanya terdapat pada $23(23,7 \%)$ subjek. Terdapat $12(12,4 \%)$ subjek yang pernah kontak dengan kasus rubela. Riwayat imunisasi MMR hanya terdapat pada 19 (19,6\%) subjek.

\section{Prevalensi Antibodi Anti-rubela}

Angka seropositif antibodi anti-rubela 71 subjek $(73,2 \%)$ dengan rerata kadar antibodi anti-rubela $159,7 \mathrm{UI} / \mathrm{ml}(\mathrm{SD}=107,4)$. Angka seronegatif 26 
Tabel 1. Karakteristik subjek penelitian

\begin{tabular}{lcc}
\hline Karakteristik subjek & Jumlah & Persentase (\%) \\
\hline Usia (tahun, rerata (SD) & 18,9 & $(1,0)$ \\
Pernah infeksi rubela sebelumnya & 23 & 23,7 \\
Pernah kontak dengan kasus rubela & 12 & 12,4 \\
Imunisasi MMR & & \\
$\quad$ MMR 1x & 19 & 19,6 \\
$\quad$ Tidak pernah & 78 & 80,4 \\
\hline
\end{tabular}

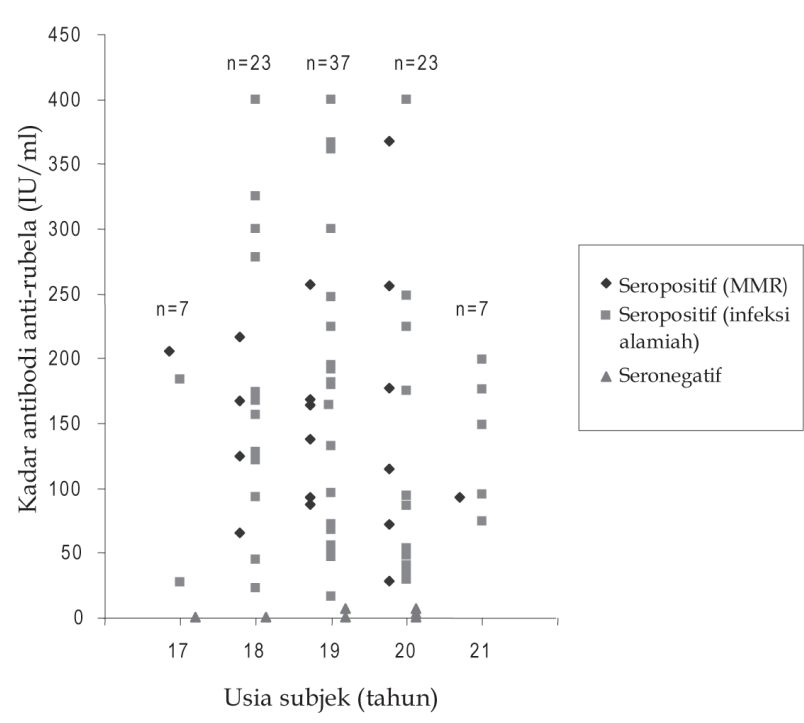

Gambar 1. Kadar antibodi anti-rubela

subjek $(26,8 \%)$ dengan rerata kadar antibodi antirubela $0,6 \mathrm{UI} / \mathrm{ml}(\mathrm{SD}=1,7)$. Prevalensi seropositif antibodi anti-rubela $73,2 \%$. Nilai rerata kadar antibodi anti-rubela $117,0 \mathrm{UI} / \mathrm{ml}(\mathrm{SD}=115,9)$.
Antibodi yang diperoleh melalui infeksi alamiah berasal dari infeksi rubela sebelumnya atau pernah kontak dengan kasus rubela. Subjek yang mempunyai titer seropositif tetapi tidak pernah mendapat imunisasi MMR, dimasukkan pada kelompok yang mendapat antibodi melalui infeksi alamiah. Infeksi alamiah terdapat pada 52 subjek penelitian $(73,2 \%)$ dengan rerata kadar antibodi anti-rubela adalah 163,6 $\mathrm{UI} / \mathrm{ml}(\mathrm{SD}=114,7)$. Antibodi yang diperoleh melalui pemberian imunisasi MMR 19 subjek (26,8\%) dengan rerata kadar antibodi anti-rubela $148,9 \mathrm{UI} / \mathrm{ml}(\mathrm{SD}=$ $86,4)$.

\section{Sebaran Antibodi Anti-rubela}

Subjek yang pernah mendapat infeksi rubela, pernah kontak dengan penderita rubela, atau pernah mendapat imunisasi MMR, seluruhnya (100\%) menunjukkan angka seropositif terhadap antibodi anti-rubela dan secara statistik berpengaruh terhadap antibodi antirubela.

\section{Pembahasan}

Antibodi terhadap rubela dapat diperoleh melalui infeksi alamiah atau setelah pemberian vaksin. Penelitian Plotkin $\mathrm{dkk}^{12}$ pada tahun 1983 yang membandingkan titer antibodi anti-rubela setelah mendapat infeksi alamiah dan setelah pemberian vaksin rubela galur RA 27/3 mendapatkan hasil titer antibodi yang didapat melalui infeksi alamiah lebih tinggi dibandingkan titer antibodi setelah vaksinasi. Titer antibodi keduanya akan menurun sejalan dengan

Tabel 2. Sebaran antibodi anti-rubela

\begin{tabular}{lccccc}
\hline \multirow{2}{*}{ Karakteristik subjek } & \multicolumn{3}{c}{ Seronegatif } & \multicolumn{3}{c}{ Seropositif } & \multirow{2}{*}{ Nilai p } \\
& $\Sigma$ & $\%$ & $\Sigma$ & $\%$ & \\
\hline $\begin{array}{l}\text { Infeksi rubela sebelumnya } \\
\quad \text { Pernah }\end{array}$ & 0 & 0 & 23 & 100 & 0,000 \\
$\quad$ Tidak pernah* & 26 & 35 & 48 & 65 & \\
$\begin{array}{l}\text { Kontak dengan kasus rubela } \\
\quad \text { Pernah }\end{array}$ & 0 & 0 & 12 & 100 & 0,025 \\
$\quad$ Tidak pernah & 26 & 30,6 & 59 & 69,4 & \\
$\begin{array}{l}\text { Imunisasi MMR } \\
\quad \text { MMR 1x }\end{array}$ & 0 & 0 & 19 & 100 & 0,003 \\
$\quad$ Tidak pernah & 26 & 33,3 & 52 & 66,7 & \\
\hline
\end{tabular}

*: termasuk subjek yang tidak tahu riwayat infeksi rubela sebelumnya 
bertambahnya waktu, tetapi dengan uji HI masih terdeteksi dan berada pada level protektif setelah 13 tahun pengamatan. ${ }^{12}$ Pada penelitian ini sebagian besar subjek $(73,2 \%)$, memperoleh antibodi setelah mengalami infeksi alamiah. Antibodi yang diperoleh melalui pemberian imunisasi MMR hanya terdapat pada 19 dari 71 subjek penelitian (26,8\%). Pada penelitian ini rerata kadar antibodi anti-rubela yang diperoleh melalui infeksi alamiah lebih tinggi dibandingkan dengan rerata kadar antibodi yang diperoleh melalui imunisasi.

Penelitian seroepidemiologi terhadap antibodi anti-rubela mendapatkan angka prevalensi yang berbeda untuk masing-masing negara. ${ }^{5,10,13-20}$ Serosurvei terhadap antibodi anti-rubela yang dilakukan di negara berkembang terhadap perempuan usia subur terdapat 13 negara dengan angka seronegatif $<10 \%$, 20 negara dengan angka seronegatif 10-24\%, dan 12 negara dengan angka seronegatif lebih dari $25 \%$. $^{4,6-7}$ Penelitian Lin DB dkk ${ }^{21}$ di Taiwan tahun 1986-1988 mendapatkan prevalensi seropositif antibodi antirubela pada anak perempuan usia $\leq 20$ tahun sebesar $64,1 \%$. Hal ini menyebabkan pemerintah Taiwan melaksanakan imunisasi rubela secara massal pada anak perempuan usia 14-15 tahun. Hasil imunisasi massal ini terlihat pada penelitian Bin-Su S dkk ${ }^{5}$ di Taiwan tahun 2000 yang mendapatkan prevalensi seropositif antibodi anti-rubela 99,7\% pada rentang usia yang sama.

Prevalensi seropositif antibodi anti-rubela yang kami temukan $73,2 \%$, menunjukkan bahwa 26,8\% subjek masih rentan terhadap infeksi rubela. Apabila kelak hamil dan mendapat infeksi rubela pada trimester pertama kehamilannya kemungkinan besar terjadi sindrom rubela kongenital. Data ini dapat dipakai sebagai asupan kebijakan pemberian imunisasi bagi perempuan usia subur. Hasil penelitian ini juga tidak jauh berbeda dengan hasil penelitian yang dilakukan Onyenekwe $\mathrm{dkk}^{18}$ di Lagos Nigeria tahun 2000 dengan prevalensi seropositif antibodi anti-rubela sebesar $77 \%$. Bila dibandingkan dengan penelitian Vijayalakshmi $\mathrm{P}$ $\mathrm{dkk}^{22}$ di New Delhi India tahun 2004 dengan prevalensi pada kelompok usia 18-19 tahun sebesar $87 \%$, maka angka yang didapatkan pada penelitian ini sedikit lebih rendah.

Serosurvei yang dilakukan di negara maju yang sudah memasukkan imunisasi MMR dalam program imunisasi rutinnya, mendapatkan prevalensi yang lebih tinggi. Penelitian Zufferey J dkk ${ }^{16}$ di Swiss tahun 1995 menyatakan prevalensi seropositif antibodi anti-rubela pada perempuan usia subur sebesar 94,3\%. Imunisasi MMR di Swiss dilakukan pada usia 5-7 tahun atau pada usia 12-15 tahun pada anak yang belum pernah mendapat imunisasi MMR sebelumnya. Penelitian Francis BH dkk ${ }^{15}$ di Australia tahun 2003 menyatakan bahwa prevalensi seropositif antibodi anti-rubela pada perempuan usia subur sebesar 97\% - 98\%. Hasil prevalensi pada penelitian ini juga lebih rendah dibandingkan dengan penelitian-penelitian di berbagai negara lainnya pada kelompok usia yang hampir sama. ${ }^{4,5,14-18,20,23-25}$

Penelitian multisenter yang dilakukan oleh Jarour

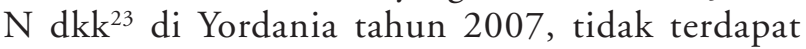
perbedaan prevalensi antara perempuan usia subur yang tinggal di perkotaan dengan yang tinggal di daerah pedesaan. Belum ada data prevalensi di daerah lain di Indonesia, tetapi pada tahun 1967 sudah dilaporkan terdapat 2 kasus sindrom rubela kongenital di RS Sutomo Surabaya. ${ }^{26}$ Pada penelitian Abdoerrachman $\mathrm{MH}^{27}$ di Jakarta tahun 1997 prevalensi seropositif antirubela pada perempuan kelompok usia 20-24 tahun sebesar 27,2\%. Kedua data membuktikan bahwa virus rubela terdapat pada berbagai daerah di Indonesia.

Antibodi anti-rubela dapat dipertahankan dalam kadar protektif dengan pemberian 2 dosis vaksin MMR. ${ }^{9} 10,14,15$ Pemberian dosis kedua perlu untuk meningkatkan titer antibodi, ${ }^{9,10,23}$ karena kadar antibodi protektif akan semakin menurun dengan bertambahnya usia. ${ }^{6,79,11}$ Apabila anak hanya mendapat satu dosis MMR masih dapat terjadi reinfeksi rubela asimtomatik. Penelitian Zanetta DMT ${ }^{10}$ di Brasil tahun 2003 mendapatkan penurunan kadar antibodi anti-rubela sebesar $10-12 \%$ setelah 8 tahun mendapatkan imunisasi MMR-1. Penelitian yang dilakukan oleh Johnson $\mathrm{dkk}^{28}$ di Amerika Serikat tahun 1996 terhadap 95 anak yang mendapat MMR II ${ }^{\circledR}$ pada usia 15 bulan, pada usia 4-6 tahun semua anak (100\%) masih menunjukkan titer seropositif, tetapi pada saat usia 1113 tahun hanya 67\% anak dengan titer seropositif. $\mathrm{Hal}$ ini menunjukkan terdapat penurunan titer antibodi rubela. Penelitian Kremer JR dkk ${ }^{9}$ di Jerman tahun 2006 mendapatkan angka seropositif 100\% untuk rubela setelah 1-8 tahun mendapatkan imunisasi MMR-2. Pengamatan yang dilakukan oleh O'Shea $\mathrm{dkk}^{29}$ di Inggris tahun 1988 menunjukkan 96,6\% subjek penelitiannya masih mempunyai titer antibodi positif setelah 10-21 tahun mendapatkan vaksinasi MMR. Pada penelitian ini semua subjek yang pernah 
mendapat imunisasi MMR (19,6\%) menunjukkan angka seropositif terhadap antibodi anti-rubela. Pada penelitian ini tidak dapat dinilai berapa lama antibodi ini bertahan karena sebagian subjek tidak ingat jadwal pemberian imunisasi MMR sebelumnya.

Menurut WHO baru 28\% negara berkembang yang sudah merekomendasikan MMR dalam program imunisasi rutin, sementara di negara maju sudah dilakukan di 92\% negara. ${ }^{7}$ Sejauh ini peneliti belum mendapatkan data angka cakupan imunisasi MMR di Indonesia. Rendahnya cakupan imunisasi MMR ini menyebabkan rubela masih merupakan masalah kesehatan yang penting dan berpotensi menyebabkan timbulnya kasus sindrom rubela kongenital. ${ }^{4-7}$

\section{Kesimpulan}

Prevalensi seropositif antibodi anti-rubela 97 remaja perempuan usia 17-21 tahun 73,2\%, dengan kadar rerata antibodi anti-rubela $159,7 \mathrm{IU} / \mathrm{ml}(\mathrm{SD}=107,4)$. Imunisasi MMR 19,6 dari 97 subjek (19,6\%). Proporsi seropositif antibodi anti-rubela yang diperoleh melalui imunisasi MMR 26,8\% dari 71 subjek dengan nilai rerata kadar antibodi anti-rubela $148,9 \mathrm{UI} / \mathrm{ml}$ $(\mathrm{SD}=86,4)$. Proporsi seropositif antibodi anti-rubela yang diperoleh melalui infeksi alamiah terdapat pada 52 dari 71 subjek penelitian $(73,2 \%)$ dengan rerata kadar antibodi anti-rubela 163,6 UI/ml (SD=114,7). Imunitas yang ditimbulkan dengan pemberian imunisasi MMR agaknya sama dengan imunitas yang diperoleh dari infeksi alamiah.

\section{Saran}

Perlu dilakukan penelitian selanjutnya pada populasi yang lebih luas untuk memperoleh angka prevalensi antibodi anti-rubela di Indonesia. Dipertimbangkan ketersediaan vaksin rubela monovalen di Indonesia bagi perempuan usia subur berusia lebih dari 15 tahun yang belum mempunyai kekebalan terhadap infeksi rubela.

\section{Daftar Pustaka}

1. Cherry JD. Rubella virus. Dalam: Feigin RD, Cherry JD, Demmier GJ, Kaplan SL, penyunting. Textbook of
Pediatric Infectious Diseases Volume 2. Edisi ke-5. Philadelphia: WB Saunders;2004.h.2134-62.

2. Gershon, AA. Rubella (German Measles). Dalam Katz SL, Gershon AA, Hotez PJ, penyunting. Krugman's Infectious Diseases of Children. Edisi ke-11. Philadelphia: Mosby;2004.h.531-44.

3. Plotkin SA, Reef S. Rubella vaccines. Dalam: Plotkin SA, Orenstein WA, penyunting, Vaccines. Edisi ke-4. Philadelpia: WB Saunders, 2004. h.707-43.

4. World Health Organization (WHO). Report of a meeting on preventing congenital rubella sindrome: immunization strategies, surveillance needs. Geneva Switzerland: Department of Vaccines and Biologicals, WHO; 2000.

5. Bin-Su S, Guo HR. Seroprevalence rubella among women of childbearing age in Taiwan after nationwide vaccination. Am J Trop Med Hyg 2002; 67: 549-53.

6. Cutts FT, Robertson SE, Diaz JL, Samuel R. Control of rubella and congenital rubella syndrome (CRS) in developing countries. Part 1: Burden of disease from CRS. Bull World Health Organ 1997;75:55-68.

7. Robertson SE, Cutt FT, Samuel R, Diaz JL. Control of rubella and congenital rubella syndrome (CRS) in developing countries. Part 2: vaccination againts rubella. Bull World Health Organ 1997;75:69-80.

8. Tseng HF, Chang CK, Tan HF, Yang SE, Chang HW. Seroepidemiology study of rubella antibodies among pregnant women from seven Asian countries: evaluation of rubella vaccination program in Taiwan. Vaccine 2006;24:5772-7.

9. Kremer JR, Scneider F, Muller CP. Waning antibodies in measles and rubella vaccinees-a longitudinal study. Vaccine 2006;24:2594-601.

10. Zanetta DMT, Cabrera EMS, Azevedo RS, Burattini MN, Massad E. Seroprevalence of rubella antibodies in State of Sao Paulo, Brazil, 8 years after the introduction of vaccine. Vaccine 2003;21:3795-800.

11. King JC, Lichenstein R, Feigelman S, Luna C, Permutt TJ, Patel J. Measles, Mumps, and Rubella antibodies in vaccinated Baltimore children. AJDC 1993;147:558-60.

12. Plotkin SA, Buser F. History of RA $27 / 3$ rubella vaccine. Rev Infect Dis 1985; suppl 1:S77-S78.

13. Zisman BR, Bazarsky EB, Skibin A, Tam G, Chamney $S$, Belmaker I. Differential immune responses to primary measles-mumps-rubella vaccination in Israeli children. Clin Dian Lab Immunol 2004;11:913-8. 39

14. Gioula G, Mataftsi ED, Daniel SA, Dalaina VK. Seroepidemiology of rubella in northern Greece. Eur J Clin Microbiol Infect Dis 2004;23:631-3. 
15. Francis BH, Thomas AK, McCarty CA. The impact of rubella immunization on the serological status of women childbearing age: a retrospective longitudinal study in Melbourne, Australia. Am J of Public Health 2003; 93:1274-6.

16. Zufferey J, Jacquier P, Chappuis S, Spinier O, Hohlfeld P, Zuber PL, et all. Seroprevalence of rubella among women of childbearing age in Switzerland. Eur J Clin Microbiol Infect Dis 1995;14:691-6.

17. Eisele CJ. Rubella susceptibility in women of childbearing age. J Obstet Gynecol Neonatal Nurs 1993;22:260-3.

18. Onyenekwee CC, Kehinde TA, Ofor US, Arinola OG. Prevalence of rubella Ig G antibody in women of childbearing age in Lagos, Nigeria. West Afr J Med 2000;19:23-6.

19. Malakmadze N, Zimmerman LA, Uzicanin A, Shteinke L, Caceres VM, Kasymbekova K. Development of rubella vaccination strategy: contribution of a rubella susceptibility study of women of childbearing age in Kyrgyzstan. Clin Infect Dis 2004;38:1780-3.

20. Mossong J, Putz L, Schneider F, Seroprevalence of measles, mumps and rubella antibodies in Luxembourg: results from a national cross-sectional study. Epidemiol Infect 2003;132:11-8.

21. Lin DB, Chen CJ. Current seroepidemiology of rubella virus infection among female residents in Taiwan. J Med Virol 1993;41:174-8.
22. Vijayalakshmi P, Anuradha R, Prakash K, Narendran K, Ravindran M, Prajna L, Brown D. Rubella serosurveys at three Aravind Eye Hospitals in Tamil Nadu, India. Bull World Health Organ 2004;82:259-64.

23. Jarour N, Hayajneh WA, Balbeesi A, Otoom H, AlShurman A, Kharabsheh S. Seroprevalence of rubella among Jordanian women of childbearing age. Vaccine 2007;30:1-4.

24. Rajasundari TA, Chandrasekar K, Vijayalakshmi P, Muthukkaruppan. Immune status of health care personnel \& post vaccination analysis of immunity againts rubella in an eye hospital. India J med Res 2006; 124:553-8.

25. Dayan GH, Panero MS, Urquiza A, Molina M, Prieto $S$, Perego MD. Rubella and measles seroprevalence among women of childbearing age, Argentina, 2002. Epidemiol Infect 2005;133:861-9.

26. Ong SK, The Soey L, Budiono LH, Djojopranoto M, Kadi J, Kristanto. Presumably congenital rubella syndrome. Paediatr Indones 1970;10:201-4

27. Abdoerrachman MH. Pemeriksaan zat anti-rubela pada ibu hamil di Jakarta. Maj Kedokt Indon 1997;47:142-5.

28. Johnson CE, Kumar MI, Whitwell JK. Antibody persistence after primary measles-mumps-rubella vaccine and response to second dose given at four to six vs eleven to thirteen years. Pediatr Infect Dis J 1996;15:687-92.

29. O'Shea S, Woodward S, Best JM. Rubella vaccination: persistence of antibodies for 10-21 years. Lancet 1988;2:909-11. 